\title{
The Evolution of the Legal Regulation of Legal Education in the Russian Empire in the XIX Century: University Reforms (Historical and Legal Aspect)
}

\author{
Sergey Alekseevich Zhinkin \\ Department of Theory and History of State and Law \\ Kuban State University \\ Krasnodar, Russia \\ E-mail: sergei.zhinkin@yandex.ru
}

Natalya Viktorovna Parshina

Department of Theory and History of State and Law of FSBEI of HE

Kuban State University

Krasnodar, Russia

E-mail: natalya.v.parshina2012@yandex.ru

\author{
Albina Alekseevna Chuprova \\ Department of Theory and History of State and Law of \\ FSBEI of HE \\ Kuban State University \\ Krasnodar, Russia \\ E-mail: chuprova.albina@yandex.ru
}

Elena Vladimirovna Epifanova

Department of Theory and History of State and Law of FSBEI of HE

Kuban State University

Krasnodar, Russia

E-mail: epifanova_elen@mail.ru

\begin{abstract}
The article is devoted to the historical and legal analysis of the formation and development of legal education in the Russian Empire in the XIX century. The article sets forth a consistent legal regulation of the consolidation of the status of law faculties in the University Charter of 1804, 1835, 1863 and 1884, their structure and evolution of functioning. The article also reflects the main content of the legal regulation of legal education, as well as the gradual consolidation in the legislation of the Russian Empire of the XIX century of compulsory legal education for government officials, including those administering justice.
\end{abstract}

Keywords-legal education; university; university reforms; legislation; judicial reform

Only enlightened peoples can

keep, understand and comply with laws;

only people familiar with the sciences

can elevate industry and agriculture;

only educated people, comprehending the price of good, can feel love and devotion for the good deeds shown to them [1].

Bulgarin F.V.

\section{INTRODUCTION}

Modern domestic legislation imposes a number of qualification requirements for persons operating in the system of law enforcement bodies of the Russian Federation. Almost all of these requirements contain the need for indepth knowledge of the current legislation [2], and in some cases a mandatory legal education is required [3]. Therefore, legal education in Russia is very popular. In almost every subject of the Russian Federation there is a corresponding faculty where future lawyers are trained. In addition, the system of Russian education, including legal education, is in a continuous stage of reform: a systematic change and addition of federal and regional legislation is underway; introduction of new standards and regulations. In this regard, of course, the need to turn to the historical past of the legislative formation and development of legal education in Russia, which took place against the background of the genesis of various socio-economic and legal phenomena (including in the "era of great reforms" - the 60s), is becoming relevant. XIX). This necessitates a comparative legal characterization of the University charters of 1804 1835, 1863 and 1884, consolidating the legal status and structure of law faculties in the system of educational institutions of the Russian Empire. This will systematize the existing legal experience of the formation and development of domestic jurisprudence. Currently, issues of modern legal education, including the practice of teaching it, are becoming the subject of research by leading Russian legal scholars, in particular, L.E. Lapteva, S.V. Kodan, V.G. Grafsky, V.A. Tomsinov, V.V. Zakharov and others.

II. LEGAL REGULATION OF LEGAL EDUCATION IN THE RUSSIAN EMPIRE IN THE FIRST HALF OF THE XIX CENTURY: CAUSES AND CONDITIONS OF EVOLUTION

The formation of legal education in Russia is associated with the activities of M.V. Lomonosov, who in 1754 drafted the structure of the Law Faculty of Moscow University [4]. Established in 1755, Moscow State University acted on the 
basis of the "Project on the Establishment of Moscow University", according to which three professors were supposed to teach at the law faculty, but in reality in the first years of its work "... the departments were empty ... one professor read at the law faculty Dilthey "[5]. Thus, the state was required to effectively organize the educational process by developing appropriate legal regulation of the activities of educational institutions.

These measures were taken during the reign of Emperor Alexander I. First of all, in 1802 the Ministry of Education was established [6]; Count P.V. became the first Minister of Education of the education of youth and the spread of sciences Zavadsky. Almost immediately after the formation of the Ministry, the state began to develop a regulatory framework governing educational activities in the Russian Empire. So, in 1803, the "Preliminary Rules for Public Education" were approved, according to which "four types of educational institutions were established for the moral education of citizens, corresponding to the duties and benefits of each state": parish schools; county provincial or gymnasium; universities [7]. Russia was divided into 6 educational districts [8]. In each district into which the Empire was divided, all educational institutions were arranged in a hierarchical order in relation to the curriculum and management [9]. That is, parish schools were the first stage of education and served as the basis for higher education at the university. In addition, a Trustee was established for each university, defined by the Imperial Majesty, who was responsible "for the improvement of all schools entrusted to him by the district." The Rules also contained rules enshrining the publication of private charters for universities "in which everything belonging to them has to be explained", including the structure of the law faculty.

The first University charter was published in 1804 [10]. The university was defined as "the highest scientific class, established for the teaching of sciences. It prepares youth for joining various ranks of the Civil Service." Analyzing the rules of the 1804 Charter, historian of Russian law, professor and rector of the Imperial Kazan University N.P. Zagoskin noted that "the preparation of state officials for various services" is thus a factor of primary importance in the emergence of Russian universities; and university professors themselves, in the eyes of the government, did not appear to be free representatives of free science, but officials ... obliged to read their courses in a strictly defined direction and according to strictly defined programs and guidelines "[11]. It should be noted that in the structure of the university, according to the Charter of 1804 , it was not provided for the establishment of a separate law faculty. According to this document, the university established 4 faculties or departments (Department of Moral and Political Sciences; Department of Physical and Mathematical Sciences; Department of Medical or Medical Sciences and the Department of Verbal Sciences). Jurisprudence was studied at the Faculty of Moral and Political Sciences (the faculty comprised a total of 8 departments, including the Interpretation of Scripture and Church History, etc.). Three departments were engaged in the study of jurisprudence (Natural, Political and People's Law; Civil and Criminal
Procedure in the Russian Empire; Rights of the most notable both ancient and modern peoples). The department of moral and political sciences "was the leading one in Russian universities at the beginning of the 19th century, and it was no accident that it was the first in the list of university departments" [12].

It is important to note that the powers of the university bodies involved participation in the resolution of disputes not related exclusively to the educational process, but also those in which teachers or students were involved even outside the university. So, in 1809, a professor at Kharkov University Coritari "entered the university's board with a complaint, in which, incidentally, he wrote that his landlord Srebdolsky made a temporary gate in the fence, separating the house occupied by him, Koritarii, from the owner's premises, - and does not want to close it; meanwhile, through it at night, "pass various suspicious people, disturbing his peace and interfering with his activities, moreover, in the stable, which fits the windows of his apartment, he is placed up to 20 in the afternoon, and at night four guard soldiers who constantly walk around the yard and pick up screaming with the owner, always drunk, and cause him anxiety and fear, so that he can not do business related to his service. The board respected Coritari's request and decided to ask the governor and the apartment commission to fulfill the legitimate desire of prof. Coritari "since occupation gg. professors demand peace on the part of the public "[13]. Thus, "the university was provided with extensive civil and criminal jurisdiction over the "scientific estate" and students" [14], with the exception of cases of real estate. It was possible to appeal the decisions of the University Board in a civil or criminal case to the Governing Senate.

Characterizing university reform at the beginning of the 19th century, it should be emphasized that in the same period, on the initiative of the statesman M.M. Speransky, the availability of education for government officials has become mandatory. Arguing the need to change the order of appointment to the public service, I.I. Meshchersky emphasized that "those who sat in the service for a long time and managed to curry favor with their superiors received ranks, distinctions, and good places. The affair suffered greatly from this. Speransky wanted to make officials more educated, replace semi-literate "assessors" with people who were knowledgeable in the sciences "[15]. As a result, the Decree of Alexander I was adopted, according to which it was ordered "in no province ... not to appoint to a civilian position requiring legal and other knowledge, people who did not graduate from a public or private school" [16], and jurisprudence entered list of required exams for state rank.

According to the University Charter of 1835 , adopted already under Nicholas I, three faculties were established at universities: philosophical, legal and medical. Studying the rules of the new Charter, professor of St. Petersburg University V.V. Grigoryev noted that “... the law faculty underwent a radical transformation. Of the subjects taught here, philosophy, history and political economy were excluded, but the teaching of legal sciences proper was expanded" [17]. Now, the following subjects were taught at the Faculty of Law: "Encyclopedia or general overview of 
the Law system, Russian State Laws, that is, Basic Laws, State Laws and State Institutions; Roman law and history thereof; Civil Laws, General, Special and Local; Laws of Improvement and Deanery; Laws on Public Duty and Finance; Laws Police and Criminal; The Beginning of Public Jurisprudence (Jus gentium)".

Despite the formation of a separate law faculty, which, of course, expanded the possibilities of training, teaching was limited mainly to studying the norms of domestic law. Criticizing this approach, Professor of the University of Kiev N.P. Yasnopolsky wrote that "the strongly predominant part of the entire course of the law faculty was then devoted to familiarizing students with current Russian legislation. The same focus on teaching in Russian alone, with only legislation, and not law in general, reveals a narrow point of view on the problem of university education at law schools, which meant preparing well-intentioned officials with a mental horizon limited to studying mainly domestic positive legislation, deprived of the opportunity to compare the latter with a foreign one ..."[18]. Undoubtedly, such a remark by the scientist regarding the rules of the Charter can be called justified and expedient. Since today "fundamental legal education presupposes the ability to understand the legal argumentation of an opponent belonging to a different legal culture" [19]. Therefore, in the program of legal education, "History of the State and the Law of Foreign Countries", along with the "History of the Russian State and the Law of Russia", is an obligatory discipline. As for the internal governance order, the powers of the university's internal governing bodies were narrowed down compared to the provisions of the 1804 Charter (now the Board did not have judicial functions).

\section{THE GENESIS OF LEGAL EDUCATION IN THE SECOND HALF OF THE XIX CENTURY: JUDICIAL REFORM AND THE PRIORITY OF GOVERNMENT AGENCIES OVER UNIVERSITY ADMINISTRATION}

The development of legal education in Russia in the second half of the XIX century: in the "era of great reforms" under Emperor Alexander II was accompanied by the adoption of the new University Charter of 1863 [20]. In accordance with this document, the following faculties were established at universities: historical and philological, physical and mathematical, legal and medical. An important change was that the list of subjects taught at the Faculty of Law was greatly expanded. According to the Charter, in the program of the law faculty, in addition to studying domestic legislation, such disciplines were included as "History of the most important foreign legislations of the oldest and newest", "History of the philosophy of law", "History of Roman law", "History of Byzantine law", "International law ", "Political Economy and Statistics ", "Church Law", etc. In addition, a radical innovation was the study of civil and criminal proceedings. Prior to this, graduates of law faculties, based on the disciplines taught at universities, had mainly theoretical knowledge, without any knowledge of the litigation process. On this occasion, an outstanding statesman of the 19th century, professor and rector of the University of St. Vladimir, N.Kh. Bunge emphasized: "We have few good lawyers ... Why? That's why we think that people in the highest positions ... cannot achieve practical, practical answers. Many of the employees who have been educated at the University do not know anything more than a few volumes of the Code of Laws and the legal practice that they have before their eyes. What order of office work we had before, which complicated it, what simplifications were made by other peoples for similar matters, what means were invented for such simplification, etc., all this is a dark forest for our practitioners "[21]. With the adoption of the Charter of 1863, the legislator took the path of expanding the field of scientific knowledge for domestic lawyers not only in the field of theoretical, but also in practical disciplines. Also, under the new Charter, the settlement of disputes concerning teachers and students was again entrusted to the "class bodies of internal university administration" [22].

The most important stage in the development of domestic jurisprudence in the second half of the XIX century: judicial reform of 1864 became the case. Thus, in accordance with the norms of the "Institution of Judicial Establishments" (Article 202), "the posts of Chairpersons, comrades of Chairpersons and members of judicial seats, including Judicial Investigators, as well as ranks of prosecutorial supervision, Ober-Secretaries, Secretaries and their Assistants "could be replaced only by persons with" certificates of universities or other higher educational institutions, on completion of a law course, or on passing an exam in these sciences, or who have proved their knowledge of the judicial part in the service "[23] . In addition, only persons "having certificates of universities or other higher educational institutions who could complete the course of legal sciences, if they, moreover, had served at least five years in the judicial department in such positions, which they could correct acquire practical information in court cases, or were also candidates for positions in the judicial department for at least five years (Art. 407), or were engaged in judicial practice under the guidance of the Sworn Attorneys, as their assistants".

Undoubtedly, it is no coincidence that the legislator made legal education compulsory for those administering justice. In the legal pre-revolutionary literature, the following characteristics of the judicial authorities were given before the 1864 reform, which clearly demonstrates the bankruptcy of the trial due to the lack of education of authorized persons: "The legal ignorance of the pre-reform judicial and investigative figures is not surprising, since most of them did not even have the proper literacy; under such conditions, it is completely clear that they did not know how to not only conduct the business that had arisen, but also to give him the proper heading. Even in the journalism of the first years of the reign of Emperor Alexander II, there were curious examples of cases "about bones found in the forest, apparently unknown to soldiers, because of the uniform button found between them", "about forged assignment of a female to a peasant boy Vasily ..." "about a brawl with hacking", "about making rampage on the face of the petty bourgeois elder", etc. "[24]. Thus, the need for legal education for persons applying for the positions of judicial and police officials, has become not only a new vector in the 
development of legal science, but also an important step in improving the quality of legal proceedings in the Russian Empire.

Further development of the system of higher legal education is associated with the adoption of the University Charter of 1884 [25]. It should be noted that, unlike the previous charters, this normative legal act was aimed, first of all, at restricting internal university self-government and strengthening the power of special state bodies (the Ministry of Public Education) in managing the educational institution. In particular, the University Court was abolished; and the Trustee (an official appointed by the Ministry of Public Education) was entrusted with the duty of "senior management in all orders", as well as the right to "give the rector binding provisions for him," that is, instructions. The structure of the university regarding the organization of the educational process remained the same (four faculties, including the law department) continued to operate. At the same time, a new department of commercial law and commercial litigation was established as part of the faculty of law [26], but the previously existing departments of "History of the most important foreign legislations, ancient and new" and "History of Slavic legislation" were abolished although they continued to study legal disciplines in within other departments.

Thus, "... during the XIX century, Universities had 4 statutes; of these, two 1804 and 1863 were built on the basis of recognition by the Universities of self-government and two of 1835 and 1884 on the weakening of this selfgovernment and on the broad subordination of universities to the authority of the trustee; the first two statutes indicated the confidence of the government in universities and their selfgovernment; the second was precisely the fruit of distrust of the Universities and the desire to subordinate them to the detailed supervision of the Minister of Education through the trustee, as his body in the school district "[27].

\section{CONCLUSION}

In general, university reforms carried out in the Russian Empire during the XIX century became the most important stage in the formation and development of domestic legal science. In addition, in the period under review, legal education was enshrined as a mandatory requirement for persons administering justice, government officials, which was a necessary foundation for Russia on the path of further state building. Legal education has become the basis for the formation and development of the most important legal institutions, a bastion of justice and legal culture, legal thinking; evolution of the system of legislation and improvement of law enforcement practice. Namely, during the XIX century, russian science was enriched by the works of outstanding jurists (Gradovsky A.D., Andrievsky I.E., Pakhman S.V., Vladimirsky-Budanov M.F., Sergeevich V.I., Tagantsev N.S., Foynitsky I.Ya., Vaskovsky E.V., Pobedonostsev K.P. and others), whose work to date, constitute an indispensable basis for studying each fundamental field of scientific knowledge of legal sciences.

\section{REFERENCES}

[1] F.V. Bulgarin, Memories. - $771 \mathrm{p}$

[2] "Directory of qualification requirements for specialties, areas of training, knowledge and skills that are necessary to fill the positions of the state civil service, taking into account the field and type of professional service of state civil servants" (approved by the Ministry of Labor of Russia) // URL: http: / /www.consultant.ru (accessed: 10/07/2019).

[3] Law of the Russian Federation dated 06.26.1992 N 3132-1 (as amended on 02.08.2019) "On the status of judges in the Russian Federation" (as amended and supplemented, entered into force on 01.09.2019) // URL: http://www.consultant.ru (accessed: 07.10.2019).

[4] M.V. Lomonosov, Complete Works. M. L. 1957, T. 10, P. 508-514.

[5] From the history of student societies in Russian universities / S. Melgunov. - Moscow: journal. Pravda, 1904. 71 p., P. 4.

[6] The manifesto on the establishment of ministries of September 8, 1802 // Complete collection of laws of the Russian Empire. SPb., Sobr. I. T. XXVII. No. 2046.

[7] A personal decree given to the Senate "On the establishment of schools" of January 24, 1803 // Complete collection of laws of the Russian Empire. SPb., Sobr. I. T. XXVII. No. 20597.

[8] Alexander I / prof. A. E. Presnyakov. - Petersburg: Brockhaus-Efron, 1924. 188 p. P.58.

[9] Historical review of the activities of the Ministry of Education. 18021902 / comp. S.V. Rozhdestvensky. - St. Petersburg: Ministry of Education, 1902. 785 p., P.50.

[10] The Highest Approved Charter of the Imperial Moscow University of November 5, 1804 // The Complete Collection of Laws of the Russian Empire. SPb., Sobr. I. T. XXVIII. No. 21498.

[11] History of the Imperial Kazan University in the first hundred years of its existence, 1804-1904 / [op.] N. P. Zagoskina, Kazan: Tipo-lithogr. Imp. Kazan University, 1902-1904. T. 1: Introduction and Part 1: (1804-1814). - 1902. 567 p., P.15.

[12] University reform of 1863 in Russia / Compiled and authored by V. A. Tomsinov. M .: Mirror, 2012. 480 p., P. L.

[13] Experience of the history of Kharkov University (based on unpublished materials) / prof. D. I. Bagaley - Kharkov: Steam Printing and Lithography Zilberberg, 1893-1898-1904. - T. 1: (18021815): the publication is illustrated with portraits of prominent figures - 1893-1898. - II, 1204 p. P. 1066.

[14] M. V. Novikov, T. B. Perfilova. The creation of a university education system in Russia and the 1804 Charter // Yaroslavl Pedagogical Bulletin - 2012 - No. 1 - Volume I (Humanities). P.15-22.

[15] Count M.M. Speransky: A brief outline of his life and state activity / I.I. Meshchersky. - St. Petersburg: Schools. owls at sv. synod, 1911 .- 47 p., P. 32.

[16] A personal decree given to the Senate "On the rules for the production of civil service ranks and on the testing in the sciences, for production at the College Assistants and State Councilors" dated August 6, 1809 // Complete collection of laws of the Russian Empire. SPb., Sobr. I. T. XXX. No. 23771.

[17] Imperial S. Petersburg University during the first fifty years of its existence: historical note / comp. on behalf of the Council of the University ordinary professor. by Caf. History of the East V.V. Grigoryev. - St. Petersburg: in Type. V. Bezobrazova, 1870 .-- 432 p., P. 109.

[18] Specialization of curricula for teaching and studying legal, state and economic sciences at Russian universities: Experience ist. researched prof. N.P. Yasnopolsky. - Kiev: type. University of St. Vladimir, AO oven. and ed. affairs N.T. Korchak-Novitsky, 1907. - VIII, 306 p., P.13-14.

[19] L.E. Lapteva. What and how do we teach? History of law and related disciplines // Materials of the seventh philosophical and legal readings in memory of academician V.S. Nersesyantsy "Encyclopedia of law or integral jurisprudence? Problems of study and teaching. "Moscow, 2013.224 p., P.155-160. 
[20] The Highest Approved General Charter of the Imperial Russian Universities of June 18, 1863 // Complete Collection of Laws of the Russian Empire. SPb., Sobr. II. T. XXXVIII. No. 39752.

[21] The connection of judicial reform with other reforms of Emperor Alexander II and its influence on the state and public life of Russia / E.N. Berendts. - Petrograd: Senate. typ., 1915. - 202 p., P.29-30.

[22] University Statute of 1863. - St. Petersburg: type. Ogrizko, 1863. - 55, 108 p., P.120.

[23] The supremely established "Institution of Judicial Establishments" of November 20, 1864 // The Complete Collection of Laws of the Russian Empire. SPb., Sobr. II. T. XXXIX. No. 41475.

[24] Judicial statutes on November 20, 1864 for fifty years: T. 1. Petrograd: Senate. typ., 1914. - 30.V. 1. 786 p., P. 28-29.

[25] Russia. Laws and regulations. General Statutes of the Imperial Russian Universities of 1863 and 1884 - Odessa: type. Acc. South Rus. Islands of Printing, 1901. - 83 p., P. 25.

[26] Comparative table of university statutes of 1884, 1863, 1835 and 1804 - St. Petersburg: Tipo-lit. St. Petersburg prison, 1901. - 270 p., P. 26.

[27] Reports of a Commission elected by the Council of Imp. University of St. Vladimir to develop answers to the questions proposed by Mr. Minister of Education on the structure of universities. - Kiev, 1901. 44 p. P.12. 